\title{
21st century bibliometric analysis of the field of dry eye disease
}

DOI:

$10.1080 / 08164622.2021 .1887581$

\section{Document Version}

Accepted author manuscript

Link to publication record in Manchester Research Explorer

\section{Citation for published version (APA):}

Nichols, J. J., Morgan, P. B., Jones, L. W., \& Efron, N. (2021). 21st century bibliometric analysis of the field of dry eye disease. Clinical and Experimental Optometry, 104(5), 639-640.

https://doi.org/10.1080/08164622.2021.1887581

\section{Published in:}

Clinical and Experimental Optometry

\section{Citing this paper}

Please note that where the full-text provided on Manchester Research Explorer is the Author Accepted Manuscript or Proof version this may differ from the final Published version. If citing, it is advised that you check and use the publisher's definitive version.

\section{General rights}

Copyright and moral rights for the publications made accessible in the Research Explorer are retained by the authors and/or other copyright owners and it is a condition of accessing publications that users recognise and abide by the legal requirements associated with these rights.

\section{Takedown policy}

If you believe that this document breaches copyright please refer to the University of Manchester's Takedown Procedures [http://man.ac.uk/04Y6Bo] or contact uml.scholarlycommunications@manchester.ac.uk providing relevant details, so we can investigate your claim.

\section{OPEN ACCESS}




\section{CLINICAL AND EXPERIMENTAL OPTOMETRY

\section{1st century bibliometric analysis of the field of dry eye disease}

\begin{tabular}{|c|c|}
\hline Journal: & Clinical and Experimental Optometry \\
\hline Manuscript ID & CEOptom-20-586-VP.R1 \\
\hline Manuscript Type: & Viewpoint \\
\hline $\begin{array}{l}\text { Date Submitted by the } \\
\text { Author: }\end{array}$ & $\mathrm{n} / \mathrm{a}$ \\
\hline Complete List of Authors: & $\begin{array}{l}\text { Nichols, Jason; University of Alabama at Birmingham, Office of Industry } \\
\text { Engagement } \\
\text { Morgan, Philip; The University of Manchester, Faculty of Life Sciences; } \\
\text { Jones, Lyndon; University of Waterloo, Optometry } \\
\text { Efron AC, Nathan; Queensland University of Technology, Insitute of } \\
\text { Health and Biomedical Innovation }\end{array}$ \\
\hline Keywords: & $\begin{array}{l}\text { bibliometric analysis, citations, dry eye, meibomian gland dysfunction, } \\
\text { publication metrics, h-index }\end{array}$ \\
\hline Abstract: & No abstract required for a Viewpoint \\
\hline
\end{tabular}

\section{SCHOLARONE ${ }^{m}$ Manuscripts}




\section{VIEWPOINT}

21 st century bibliometric analysis of the field of dry eye disease

Jason J Nichols* OD MPH PhD

Philip B Morgan ${ }^{\dagger} \mathrm{PhD}$ BSc(Hons) MCOptom

Lyndon W Jones ${ }^{\ddagger} \mathrm{DSc}$ PhD BSc(Hons) FCOptom

Nathan Efron ${ }^{\S}$ AC DSc PhD BScOptom

*School of Optometry, The University of Alabama at Birmingham, Birmingham, Alabama, USA

${ }^{\dagger}$ Eurolens Research, Division of Pharmacy and Optometry, The University of Manchester, Manchester, UK tCentre for Ocular Research \& Education (CORE), School of Optometry and Vision Science, University of Waterloo, Waterloo, Ontario, Canada and Centre for Eye and Vision Research (CEVR), Hong Kong Special Administrative Region

${ }^{\S}$ School of Optometry and Vision Science, Queensland University of Technology, Kelvin Grove, Queensland, Australia

Submitted:

Revised:

Accepted:

\section{[Running head]}

Dry eye publication metrics

Key words: bibliometric analysis, citations, dry eye, meibomian gland dysfunction, publication metrics, h-index

\section{[Corresponding author]}

Nathan Efron

n.efron@qut.edu.au 


\section{[Introduction]}

In 2012, the lead author of this paper (JJN) conducted a citation analysis of dry eye research to identify the leading papers, authors, institutions, countries and journals in the field. ${ }^{1}$ That analysis was essentially an historical overview of publications on this topic extending back over the past century. Because a strong and growing foundation of scientific literature is a fundamental component of evidenced-based clinical care of patients, the current work was conducted to update the research community on trends in the $21^{\text {st }}$ century dry eye literature, and to compare this new literature with the prior analysis in the context of events or trends in the dry eye field.

\section{Search strategy}

The search protocol used here was undertaken using the Scopus database (Elsevier) on December 30, 2020 and was restricted to all document types published in journals in English between 2001 and 2021. The following search term was derived to ensure (a) high sensitivity, including a wide capture of articles with "dry eye" as the primary theme, and (b) high specificity, so as to rule out irrelevant or peripherally related articles:

\section{TITLE $(\{$ dry eye $\}$ OR \{dry-eye $\}$ OR \{dry eyes $\}$ OR \{tear physiology $\}$ OR \{tear fluid $\}$ OR $\{$ TFOS $\}$ OR \{DEWS \} OR \{meibum\} OR \{meibomian\} OR \{blepharitis\} OR \{ocular surface disease OR \{ocular surface\} OR \{tear film\} OR \{tear-film\} OR (keratoconjunctivitis AND sicca) OR \{dysfunctional tear syndrome\} OR \{tear-fluid\} OR \{punctal plug\} OR (lacrimal) OR \{tear cytokine\} OR (ocular W/10 symptom*) OR \{ocular mucin \} OR (biochemistry W/10 tears) OR (sjogrens W/20 ocular) OR (Sjogren $\mathrm{W} / 20$ tears) OR (cyclosporine W/10 ophthalmic) OR (mcmonnie*) OR (p2y2 W/20 ocular)) AND (PUBYEAR > 2000) AND (LIMIT-TO(SRCTYPE, "j")) AND (LIMIT-TO(LANGUAGE, "English"))}

The search revealed 10,178 dry eye-related papers, from which the top 25 most cited papers could be determined by simple sorting within Scopus. A subject-specific h-index for 'dry eye' (the " $\mathrm{h}_{\mathrm{DE}}$-index") was derived, to serve as a measure of the impact of authors, institutions, countries and journals in the field of dry eye research. The detailed methodology for determining the subject-specific-index and identifying the topranked entities in each of these categories is the same as that employed by Efron et al ${ }^{2}$ and will not be repeated here.

In considering these data, it is important to note that the different categories are not necessarily mutually exclusive (i.e. the most prominent papers, authors, countries and institutions are likely to be somewhat associated). 


\section{Highly cited papers}

As shown in Figure 1, the volume of dry eye literature has rapidly increased during the $21^{\text {st }}$ century such that approximately 1,150 papers will be published in 2020 (compared with an average of 444 papers per year over the 20 year span). The $\mathrm{h}_{\mathrm{DE}}$-index for all 10,178 articles in this field is 151 , attracting 196,364 citations; $18.1 \%$ of these articles have never been cited.

The 25 most highly cited papers are listed in Table 1 of the Supplementary Material. While the topics are broad, nine of the top 25 articles relate to international workshops in meibomian gland dysfunction and dry eye disease; seven relate to tests, symptoms and outcomes; and seven relate to the prevalence of the disease.

\section{Most impactful authors}

Table 2 of the Supplementary Material lists the 25 most impactful authors of the $21^{\text {st }}$ century, ranked by $h_{D^{-}}$ index, along with the total count of dry eye-related papers published. The most impactful authors have individually published between 29 and 275 papers specifically related to dry eye between 2001-2021, and have $\mathrm{h}_{\mathrm{DE}}$-indices ranging from 24 to 56.

Kazuo Tsubota is the top-ranked author with a $\mathrm{h}_{\mathrm{DE}}$-index of 56 (he was also ranked \#1 in 20121), with the next author separated by seven $\mathrm{h}_{\mathrm{DE}}$-index points. Dr Tsubota is also the most prolific author by a wide margin; he has published 275 dry eye-related papers, which is more than double the output \#2-ranked Murat Dogru (134 papers). Of the top 25 authors, the majority are ophthalmologists, and three are optometrists - Kelly Nichols (rank \#5), Jason Nichols (\#11), and Alan Tomlinson (\#22).

\section{Leading institutions}

The top 25 institutions from which papers emanated in the $21^{\text {st }}$ century dry eye literature are listed in Table 3 of the Supplementary Materials, ranked by $\mathrm{h}_{\mathrm{DE}}$-index, along with the total paper count. Harvard University is the leading institution with a $\mathrm{h}_{\mathrm{DE}}$-index of 71; this university was also ranked $\# 1$ in the 2012 listing. ${ }^{1}$ Institutions from the United States and Japan dominate the Top 10 list (12 institutions), with the University of New South Wales (rank \#8) making an entry into the Top 10 in the current analysis.

\section{Top countries}

Table 4 of the Supplementary Material lists the top 25 countries, ranked by $\mathrm{h}_{\mathrm{DE}}$-index, along with the total paper count. The United States retains top ranking, with a $\mathrm{h}_{\mathrm{DE}}$-index of 123 , followed by Japan, the United Kingdom, Australia and Spain. The top three remain the same as 2012, ${ }^{1}$ while Australia is elevated in the rankings, rising from rank $\# 8$ to $\# 4$. 


\section{Prominent journals}

The top 25 journals publishing dry eye-related articles in the $21^{\text {st }}$ century are listed in Table 5 of the Supplementary Material, ranked by $\mathrm{h}_{\mathrm{DE}}$-index, as well as the total paper count. The top journal remains Investigative Ophthalmology and Visual Science, with an $\mathrm{h}_{\mathrm{DE}}$-index of 81; this journal also topped the rankings in $2012 .{ }^{1}$ Fourteen of the 25 top-ranked journals are ophthalmology-based, having the word "ophthalmology" or "surgery" in the journal name (as well as the journal Eye, which is the official journal of the Royal College of Ophthalmologists in the United Kingdom)

\section{Conclusions}

The dry eye literature has shown considerable growth in the $21^{\text {st }}$ century, with about 450 papers published each year in this field. Of the Top 25 papers published between 2001 and 2021, only two have been published since the 2012 bibliometric analysis ${ }^{1}$ - both being part of the TFOS Dry Eye Workshop II (Table 1 of the Supplementary Material; papers ranked \#5 and \#15). ${ }^{3}$ Three of the Top 25 papers originated from the TFOS International Workshop on Meibomian Gland Dysfunction (Table 1 of the Supplementary Material; papers ranked \#12, \#13, and \#20), which concluded in $2011 .{ }^{4}$

There has been a considerable rearrangement of the ranking of the Top 25 authors in the dry eye field, with many new entries on the list. Of the top 25 authors, Reza Dana was not ranked previously and is now ranked \#7. Of those with a prior ranking, Kelly Nichols saw the greatest increase of 11 ranks, from \#16 in 2012 to \#5 in the current analysis.

The dry eye field has remained somewhat consistent in trends in top ranked countries and institutions, with some minor changes in these areas such as the greater prominence of Australia and Spain in dry eye research. There has been some variability in journal rankings. Although the top three journals have remained consistent, The Ocular Surface has risen in prominence from rank \#19 to \#4; this is probably because it was a newer journal in 2012 and the findings of the initial TFOS International Dry Eye Workshop, which were published in this journal, have been highly cited.

\section{REFERENCES}

1 Nichols JJ. Citation analysis of the dry eye literature. Ocular Surface 2013; 11: 35-46.

2 Efron N, Morgan P, Jones L et al. 21st century citation analysis of the field of contact lenses. Clin Exp Optom (in press).

3 Nelson JD, Craig JP, Akpek EK et al. TFOS DEWS II introduction. The Ocular Surface 2017; 15: 269275. 
4 Nichols KK, Foulks GN, Bron AJ et al. The international workshop on meibomian gland dysfunction: Executive summary. Invest Ophthalmol Vis Sci 2011; 52: 1922-1929. 


\section{[Figure caption]}

Figure 1. Number of papers in the field of dry eye field published between 2001-2020. 


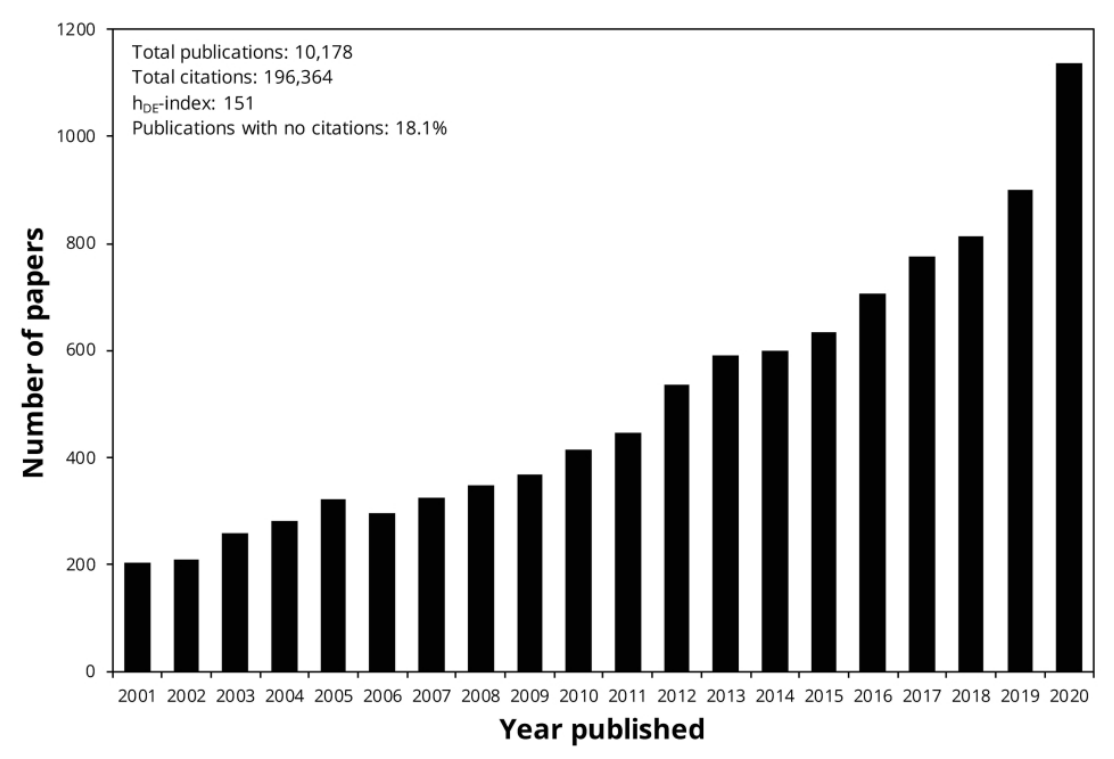

$297 \times 209 \mathrm{~mm}(300 \times 300$ DPI $)$ 


\section{Supplementary Material}

Table 1. Top 25 most cited dry eye-related articles published in the $21^{\text {st }}$ century, ranked by author $h_{D E}$-index. Comparison with 2012 ranking provided. NR = not ranked. Note that several articles in the 2012 analysis are not included here as they were published before 2001 and outside the scope of the current search parameters.

\begin{tabular}{|c|c|c|c|c|c|c|}
\hline Rank & Title & First Author & Journal & $\begin{array}{l}\text { Year, Volume } \\
\& \text { Pages }\end{array}$ & Citations & $\begin{array}{l}2012 \\
\text { Rank }\end{array}$ \\
\hline 1 & $\begin{array}{l}\text { The definition and classification of dry eye } \\
\text { disease: Report of the definition and } \\
\text { classification subcommittee of the } \\
\text { international dry eye workshop }\end{array}$ & Michael Lemp & The Ocular Surface & $\begin{array}{c}2007 \\
5 ; 75-92\end{array}$ & 1947 & NR \\
\hline 2 & $\begin{array}{l}\text { Prevalence of dry eye syndrome among } \\
\text { US women }\end{array}$ & Debra Schaumberg & $\begin{array}{l}\text { American Journal } \\
\text { of Ophthalmology }\end{array}$ & $\begin{array}{c}2003 \\
136 ; 318-26\end{array}$ & 804 & 21 \\
\hline 3 & $\begin{array}{l}\text { The epidemiology of dry eye disease: } \\
\text { Report of the epidemiology subcommittee } \\
\text { of the international Dry Eye Workshop }\end{array}$ & Janine Smith & The Ocular Surface & $\begin{array}{c}2007 \\
5 ; 93-107\end{array}$ & 749 & NR \\
\hline 4 & $\begin{array}{l}\text { Grading of corneal and conjunctival } \\
\text { staining in the context of other dry eye } \\
\text { tests }\end{array}$ & Anthony Bron & Cornea & $\begin{array}{c}2003 \\
22 ; 640-50\end{array}$ & 611 & NR \\
\hline 5 & TFOS DEWS II definition and classification & Jennifer Craig & The Ocular Surface & $\begin{array}{c}2017 \\
15 ; 276-83\end{array}$ & 599 & NR \\
\hline 6 & $\begin{array}{l}\text { Chitosan nanoparticles: A new vehicle for } \\
\text { the improvement of the delivery of drugs } \\
\text { to the ocular surface. Application to } \\
\text { Cyclosporine A }\end{array}$ & Angela DeCampos & $\begin{array}{l}\text { International } \\
\text { Journal of } \\
\text { Pharmaceuticals }\end{array}$ & $\begin{array}{c}2001 \\
224 ; 159-68\end{array}$ & 548 & NR \\
\hline 7 & $\begin{array}{l}\text { Methodologies to diagnose and monitor } \\
\text { dry eye disease: Report of the diagnostic } \\
\text { methodology subcommittee of the } \\
\text { international Dry Eye Workshop }\end{array}$ & Anthony Bron & The Ocular Surface & $\begin{array}{c}2007 \\
5 ; 108-152\end{array}$ & 519 & NR \\
\hline 8 & $\begin{array}{l}\text { Pro- and anti-inflammatory forms of } \\
\text { interleukin- } 1 \text { in the tear fluid and } \\
\text { conjunctiva of patients with dry-eye } \\
\text { disease }\end{array}$ & Abraham Solomon & $\begin{array}{l}\text { Investigative } \\
\text { Ophthalmology } \\
\text { and Visual Science }\end{array}$ & $\begin{array}{c}2001 \\
42 ; 2283-92\end{array}$ & 519 & 23 \\
\hline 9 & $\begin{array}{l}\text { Functional aspects of the tear film lipid } \\
\text { layer }\end{array}$ & Anthony Bron & $\begin{array}{l}\text { Experimental Eye } \\
\text { Research }\end{array}$ & $\begin{array}{c}2004 \\
78 ; 347-60\end{array}$ & 499 & NR \\
\hline 10 & $\begin{array}{l}\text { The lack of association between signs and } \\
\text { symptoms in patients with dry eye disease }\end{array}$ & Kelly Nichols & Cornea & $\begin{array}{c}2004 \\
23 ; 762-70\end{array}$ & 485 & NR \\
\hline 11 & $\begin{array}{l}\text { The impact of dry eye syndrome on vision- } \\
\text { related quality of life }\end{array}$ & Biljana Miljanovic & $\begin{array}{l}\text { American Journal } \\
\text { of Ophthalmology }\end{array}$ & $\begin{array}{c}2007 \\
143 ; 409-15\end{array}$ & 481 & NR \\
\hline 12 & $\begin{array}{l}\text { The international workshop on meibomian } \\
\text { gland dysfunction: Report of the } \\
\text { subcommittee on anatomy, physiology, } \\
\text { and pathophysiology of the meibomian } \\
\text { gland }\end{array}$ & Erik Knop & $\begin{array}{l}\text { Investigative } \\
\text { Ophthalmology } \\
\text { and Visual Science }\end{array}$ & $\begin{array}{c}2011 \\
52 ; 1938-78\end{array}$ & 447 & NR \\
\hline
\end{tabular}




\begin{tabular}{|c|c|c|c|c|c|c|}
\hline 13 & $\begin{array}{l}\text { The international workshop on meibomian } \\
\text { gland dysfunction: Executive summary }\end{array}$ & Kelly Nichols & $\begin{array}{l}\text { Investigative } \\
\text { Ophthalmology } \\
\text { and Visual Science }\end{array}$ & $\begin{array}{c}2011 \\
52 ; 1922-9\end{array}$ & 435 & NR \\
\hline 14 & $\begin{array}{l}\text { Cultivated corneal epithelial stem cell } \\
\text { transplantation in ocular surface disorders }\end{array}$ & Noriko Koizumi & Ophthalmology & $\begin{array}{c}2001 \\
108 ; 1569-74\end{array}$ & 413 & NR \\
\hline 15 & TFOS DEWS II epidemiology report & Fiona Stapleton & The Ocular Surface & $\begin{array}{c}2017 \\
15 ; 334-365\end{array}$ & 411 & NR \\
\hline 16 & $\begin{array}{l}\text { Prevalence of ocular symptoms and signs } \\
\text { with preserved and preservative free } \\
\text { glaucoma medication }\end{array}$ & Pierre-Jean Pisella & $\begin{array}{l}\text { British Journal of } \\
\text { Ophthalmology }\end{array}$ & $\begin{array}{c}2002 \\
86 ; 418-23\end{array}$ & 411 & NR \\
\hline 17 & $\begin{array}{l}\text { Prevalence of dry eye among an elderly } \\
\text { Chinese population in Taiwan: The Shihpai } \\
\text { eye study }\end{array}$ & Pei-Yu Lin & Ophthalmology & $\begin{array}{c}2003 \\
110 ; 1096-101\end{array}$ & 407 & NR \\
\hline 18 & $\begin{array}{l}\text { Management and therapy of dry eye } \\
\text { disease: Report of the management and } \\
\text { therapy subcommittee of the international } \\
\text { dry eye workshop }\end{array}$ & Steve Pflugfelder & The Ocular Surface & $\begin{array}{c}2007 \\
5 ; 163-178\end{array}$ & 402 & NR \\
\hline 19 & $\begin{array}{l}\text { Experimental dry eye stimulates } \\
\text { production of inflammatory cytokines and } \\
\text { MMP- } 9 \text { and activates MAPK signaling } \\
\text { pathways on the ocular surface }\end{array}$ & Lihui Luo & $\begin{array}{l}\text { Investigative } \\
\text { Ophthalmology } \\
\text { and Visual Science }\end{array}$ & $\begin{array}{c}2004 \\
45 ; 4293-301\end{array}$ & 388 & NR \\
\hline 20 & $\begin{array}{l}\text { The international workshop on meibomian } \\
\text { gland dysfunction: Report of the definition } \\
\text { and classification subcommittee }\end{array}$ & J Daniel Nelson & $\begin{array}{l}\text { Investigative } \\
\text { Ophthalmology } \\
\text { and Visual Science }\end{array}$ & $\begin{array}{c}2011 \\
52 ; 1930-7\end{array}$ & 366 & NR \\
\hline 21 & $\begin{array}{l}\text { Tear film osmolarity: Determination of a } \\
\text { referent for dry eye diagnosis }\end{array}$ & Alan Tomlinson & $\begin{array}{l}\text { Investigative } \\
\text { Ophthalmology } \\
\text { and Visual Science }\end{array}$ & $\begin{array}{c}2006 \\
47 ; 4309-15\end{array}$ & 362 & NR \\
\hline 22 & $\begin{array}{l}\text { Tear osmolarity in the diagnosis and } \\
\text { management of dry eye disease }\end{array}$ & Michael Lemp & $\begin{array}{l}\text { American Journal } \\
\text { of Ophthalmology }\end{array}$ & $\begin{array}{c}2011 \\
151 ; 792-8\end{array}$ & 361 & NR \\
\hline 23 & $\begin{array}{l}\text { Prevalence of dry eye disease among US } \\
\text { men: Estimates from the physicians' health } \\
\text { studies }\end{array}$ & Debra Schaumberg & $\begin{array}{l}\text { Archives of } \\
\text { Ophthalmology }\end{array}$ & $\begin{array}{c}2009 \\
127 ; 763-8\end{array}$ & 361 & NR \\
\hline 24 & $\begin{array}{l}\text { Dysfunctional tear syndrome: A Delphi } \\
\text { approach to treatment recommendations }\end{array}$ & Ashley Behrens & Cornea & $\begin{array}{c}2006 \\
25 ; 900-7\end{array}$ & 359 & 24 \\
\hline 25 & $\begin{array}{l}\text { Prevalence of ocular surface disease in } \\
\text { glaucoma patients }\end{array}$ & Eamon Leung & $\begin{array}{l}\text { Journal of } \\
\text { Glaucoma }\end{array}$ & $\begin{array}{c}2008 \\
17 ; 350-5\end{array}$ & 357 & NR \\
\hline
\end{tabular}


Table 2. Top 25 authors of dry eye-related articles published in the $21^{\text {st }}$ century, ranked by author $h_{D E}$-index. Comparison with 2012 ranking provided. NR = not ranked. Note that several authors in the 2012 analysis are not included here as the bulk of their publications occurred before 2001 and outside the scope of the current search parameters.

\begin{tabular}{|c|c|c|c|c|}
\hline Rank & Author & $h_{D E}$-index & Paper count & 2012 Rank \\
\hline 1 & Kazuo Tsubota & 56 & 275 & 1 \\
\hline 2 & Steve Pflugfelder & 49 & 128 & 2 \\
\hline 3 & Murat Dogru & 48 & 134 & 3 \\
\hline 4 & Shigeru Kinoshita & 40 & 106 & 11 \\
\hline 5 & Kelly Nichols & 40 & 80 & 16 \\
\hline 6 & Christophe Baudouin & 38 & 119 & 7 \\
\hline 7 & Reza Dana & 36 & 79 & NR \\
\hline 8 & Norihiko Yokoi & 34 & 87 & 17 \\
\hline 9 & David Sullivan & 34 & 77 & 4 \\
\hline 10 & Michael Stern & 34 & 65 & 10 \\
\hline 11 & Jason Nichols & 33 & 71 & 14 \\
\hline 12 & Gary Foulks & 32 & 75 & 24 \\
\hline 13 & Cintia de Paiva & 32 & 73 & 15 \\
\hline 14 & Jun Shimazaki & 32 & 59 & 18 \\
\hline 15 & Yukihiro Matsumoto & 31 & 52 & 8 \\
\hline 16 & Anat Galor & 29 & 105 & NR \\
\hline 17 & Eiki Goto & 28 & 44 & 9 \\
\hline 18 & Debra Schaumberg & 27 & 35 & NR \\
\hline 19 & Louis Tong & 25 & 99 & NR \\
\hline 20 & Margarete Cologne & 25 & 42 & NR \\
\hline 21 & Takahiro Nakamura & 25 & 39 & NR \\
\hline 22 & Alan Tomlinson & 25 & 32 & NR \\
\hline 23 & Dequan Li & 25 & 29 & 13 \\
\hline 24 & Gerd Geerling & 24 & 60 & NR \\
\hline 25 & Miki Uchino & 24 & 50 & NR \\
\hline
\end{tabular}


Table 3. Top 25 institutions of dry eye-related articles published in the $21^{\text {st }}$ century, ranked by institution $\mathrm{h}_{\mathrm{DE}}$-index. Comparison with 2012 ranking provided. NR = not ranked. Note that several institutions in the 2012 analysis are not included here as the bulk of their publications were published before 2001 and outside the scope of the current search parameters.

\begin{tabular}{|c|c|c|c|c|c|}
\hline Rank & Institution & Country & $H_{D E}$-index & Paper count & 2012 Rank \\
\hline 1 & Harvard University ${ }^{\mathrm{a}}$ & United States & 71 & 437 & 1 \\
\hline 2 & Keio University & Japan & 60 & 295 & 2 \\
\hline 3 & Baylor College of Medicine ${ }^{b}$ & United States & 48 & 148 & 6 \\
\hline 4 & Tokyo Dental College & Japan & 47 & 123 & 4 \\
\hline 5 & Kyoto Prefectural University of Medicine & Japan & 44 & 154 & 16 \\
\hline 6 & University of Miamic $^{\mathrm{C}}$ & United States & 42 & 201 & 8 \\
\hline 7 & Ohio State University & United States & 40 & 109 & 5 \\
\hline 8 & University of New South Wales & Australia & 39 & 157 & 14 \\
\hline 9 & Allergan & United States & 38 & 101 & 13 \\
\hline 10 & UT Southwestern Medical Center/School & United States & 35 & 76 & NR \\
\hline 11 & Quinze-Vingts National Ophthalmology Hospital & France & 34 & 111 & NR \\
\hline 12 & University of Waterloo & Canada & 33 & 104 & 20 \\
\hline 13 & National Singapore University ${ }^{d}$ & Singapore & 32 & 164 & NR \\
\hline 14 & University of Houston & United States & 30 & 61 & NR \\
\hline 15 & Glasgow Caledonian University & United Kingdom & 30 & 53 & 17 \\
\hline 16 & University of Louisville & United States & 29 & 65 & 25 \\
\hline 17 & Johns Hopkins University ${ }^{\mathrm{e}}$ & United States & 28 & 111 & 19 \\
\hline 18 & National Institute for Health and Medical Research & France & 28 & 102 & NR \\
\hline 19 & Universita degli Studi di Genova & Switzerland & 28 & 55 & NR \\
\hline 20 & University of Oxford & United Kingdom & 27 & 48 & 11 \\
\hline 21 & University of Southern California ${ }^{f}$ & United States & 26 & 131 & 3 \\
\hline 22 & Sorbonne University & France & 26 & 86 & NR \\
\hline 23 & Fudan University ${ }^{g}$ & China & 25 & 94 & NR \\
\hline 24 & VA Medical Center & United States & 25 & 80 & NR \\
\hline 25 & University of California, Berkeley & United States & 25 & 70 & NR \\
\hline
\end{tabular}

aIncludes Harvard Medical School, Schepens Eye Research Institute, Brigham and Women's Hospital, and Massachusetts Eye and Ear Infirmary.

bIncludes Cullen Eye Institute.

Includes Bascom Palmer Eye Institute.

dIncludes National University of Singapore, Faculty of Medicine, Singapore Eye Research Institute, Singapore National Eye Center, DukeNUS Medical School Singapore, and Yong Loo Lin School of Medicine.

encludes the Wilmer Eye Institute.

fIncludes the Keck School of Medicine and School of Pharmacy.

Includes Eye and ENT Hospital of Fudan University. 
Table 4. Top 25 countries of dry eye-related articles published in the $21^{\text {st }}$ century, ranked by country $h_{D E}$-index. Comparison with 2012 ranking provided. NR = not ranked. Note that several countries in the 2012 analysis are not included here as the bulk of their publications were published before 2001 and outside the scope of the current search parameters.

\begin{tabular}{|c|c|c|c|c|}
\hline Rank & Country & $\mathbf{h}_{\mathrm{DE} \text {-index }}$ & Paper count & 2012 Rank \\
\hline 1 & United States & 123 & 3,140 & 1 \\
\hline 2 & Japan & 81 & 967 & 2 \\
\hline 3 & United Kingdom & 74 & 783 & 3 \\
\hline 4 & Australia & 55 & 448 & 8 \\
\hline 5 & Germany & 53 & 423 & 4 \\
\hline 6 & Spain & 53 & 401 & 11 \\
\hline 7 & Italy & 51 & 461 & 7 \\
\hline 8 & China & 50 & 857 & 6 \\
\hline 9 & Canada & 44 & 288 & 9 \\
\hline 10 & France & 43 & 266 & 5 \\
\hline 11 & South Korea & 42 & 536 & 14 \\
\hline 12 & Turkey & 37 & 495 & 10 \\
\hline 13 & Singapore & 37 & 186 & NR \\
\hline 14 & Brazil & 32 & 222 & 13 \\
\hline 15 & India & 31 & 618 & 12 \\
\hline 16 & Austria & 24 & 91 & 18 \\
\hline 17 & Sweden & 23 & 88 & 16 \\
\hline 18 & Netherlands & 21 & 69 & 15 \\
\hline 19 & Denmark & 21 & 61 & 19 \\
\hline 20 & Taiwan & 19 & 139 & NR \\
\hline 21 & Poland & 19 & 117 & 23 \\
\hline 22 & New Zealand & 19 & 88 & NR \\
\hline 23 & Greece & 19 & 72 & 24 \\
\hline 24 & Switzerland & 19 & 64 & 20 \\
\hline 25 & Finland & 19 & 57 & 22 \\
\hline
\end{tabular}


Table 5. Top 25 journals of dry eye-related articles published in the $21^{\text {st }}$ century, ranked by journal $\mathrm{h}_{\mathrm{DE}}$-index. Comparison with 2012 ranking provided. NR = not ranked. Note that several journals in the 2012 analysis are not included here as the bulk of their publications were published before 2001 and outside the scope of the current search parameters.

\begin{tabular}{|c|c|c|c|c|}
\hline Rank & Journal & $h_{D E}$-index & Paper count & 2012 Rank \\
\hline 1 & Investigative Ophthalmology and Visual Science & 81 & 599 & 1 \\
\hline 2 & Cornea & 64 & 613 & 2 \\
\hline 3 & American Journal of Ophthalmology & 59 & 235 & 4 \\
\hline 4 & The Ocular Surface & 56 & 426 & 19 \\
\hline 5 & Ophthalmology & 54 & 207 & 6 \\
\hline 6 & Experimental Eye Research & 49 & 176 & 8 \\
\hline 7 & British Journal of Ophthalmology & 46 & 224 & 5 \\
\hline 8 & Archives of Ophthalmology/JAMA Ophthalmology & 40 & 130 & 7 \\
\hline 9 & Optometry and Vision Science & 36 & 143 & 10 \\
\hline 10 & Current Eye Research & 34 & 198 & 9 \\
\hline 11 & Eye and Contact Lens & 30 & 199 & NR \\
\hline 12 & Eye & 29 & 146 & 18 \\
\hline 13 & PLOS ONE & 28 & 147 & NR \\
\hline 14 & Molecular Vision & 27 & 62 & 24 \\
\hline 15 & Clinical Ophthalmology & 25 & 213 & NR \\
\hline 16 & Contact Lens and Anterior Eye & 25 & 158 & NR \\
\hline 17 & Graefe's Archive for Clinical and Experimental Ophthalmology & 25 & 100 & 14 \\
\hline 18 & Ophthalmic Plastic and Reconstructive Surgery & 24 & 285 & 13 \\
\hline 19 & Journal of Ocular Pharmacology and Therapeutics & 24 & 105 & NR \\
\hline 20 & Journal of Cataract and Refractive Surgery & 23 & 45 & 23 \\
\hline 21 & European Journal of Ophthalmology & 21 & 108 & 25 \\
\hline 22 & Acta Ophthalmologica & 21 & 91 & 22 \\
\hline 23 & Clinical and Experimental Ophthalmology & 20 & 89 & NR \\
\hline 24 & Japanese Journal of Ophthalmology & 20 & 62 & NR \\
\hline 25 & Ophthalmic Research & 17 & 52 & NR \\
\hline
\end{tabular}

